\title{
Solitude and the Consent of Language: Marosa di Giorgio and Emily Dickinson.
}

\author{
Anna Deeny \\ Georgetown University \\ ad1414@georgetown.edu
}

\begin{abstract}
"Solitude and the Consent of Language: Marosa di Giorgio and Emily Dickinson," examines how the Uruguayan, Marosa di Giorgio, draws from Emily Dickinson's poetry to imagine the mind's solitude as a recuperation of linguistic and signifying freedom within the acute context of imposed consent during the Uruguayan dictatorship. I suggest that the question at work within both poet's oeuvre has to do with how poetic form might access the tension between what each understood as the mind's solitude, that is, its individual interpretive processes, and the pulls of communal life, which include governmental, juridical, narrative and pedagogical systems, as they are negotiated through language. In addition to being an interdisciplinary analysis that brings together the fields of philosophy, U.S., and Latin American letters, this paper calls attention to two women writers who are rarely considered together within literary and cultural studies.
\end{abstract}


Keywords: Marosa di Giorgio; Emily Dickinson; solitude; consent; John Locke; poetry.

\section{Resumen}

"Soledad y consentimiento del lenguaje: Marosa di Giorgio y Emily Dickinson" considera cómo la uruguaya, Marosa di Giorgio, coincide con la escritora decimonónica, Emily Dickinson, en su figuración poética de la soledad y el lenguaje tal como existen en tensión con los mecanismos sociales que difunden y estandarizan un lenguaje común y los dominios del conocimiento. Además de ser un análisis interdisciplinario que alude a los campos de la filosofía, y la historia cultural de los Estados Unidos y de las letras latinoamericanas, este artículo estudia la obra de dos mujeres escritoras que rara vez se consideran juntas dentro de los estudios literarios y culturales.

Palabras clave: Marosa di Giorgio; Emily Dickinson; soledad; consentimiento; John Locke; poesía.

Estoy en la misma casa. El viento sacude los álamos apaches y los cáñamos donde un día las hadas dejaron su proposición de azúcar y de sal.

Allá, en la cocina, el ama de llaves picotea las ciruelas, los capullos, las antiguas carnes de cerdo salvaje.

Y no hay nadie más.

Junto los lápices, los cuadernos, y los desparramo.

Lejos, se quedan las poblaciones y los príncipes.

Estaré, siempre, en la rama natal, en el nido de los tules y la o.

-Marosa di Giorgio, "104," Clavel y tenebrario

[I'm in the same house. The wind shakes apache poplars and hemp where fairies once left their gift of sugar and salt.

Over there, in the kitchen, the housekeeper pecks at plums, buds, the old wild hog meats.

And there is no one else. 
I gather the pencils, the notebooks, and scatter them.

Far away, towns and princes remain.

I will be, always, on the branch where I was born, in the nest of tulles and o. $]^{1}$

Marosa di Giorgio's oeuvre depicts country homes populated by things like fairies, personified flora and fauna, precariously wandering children and adolescents, unknown languages, metamorphoses, and bestiality. As in the case of the poem above, di Giorgio grounds such manifold elements, that critics have tentatively described as neo-baroque, kitsch, and lo maravilloso negro, in the speaker's constant solitude. (Achugar "Kitsch"; Echevarren; OliveraWilliams; and Bravo). And just as di Giorgio's oeuvre seems to circumvent facile categorization, the solitude within her poems always stands in opposition to various forces of communal belonging. In this poem, from Clavel y tenebrario (Carnation and Tenebrae) (1979), the poetic voice maps a "house" that includes what is "there" and also what is "[f]ar away." The "I" orders and disorders scholastic tools that disseminate as well as standardize a common language and domains of knowledge. The poetic voice is alone, remote from "towns" and "princes," governments, urban communities and sovereigns. This spatial stance is temporally intensified through "I am" and "I will always be," and then centered in a diaphanous nest of tulle. Like the brain's meters of folded surfaces, the nest of tulle carries the "o," which is as much the shape of an egg, as a vowel sound and the word for "or" in Spanish. "[O]" recalls the unfurling fabric of meaning, the constant bend of this "or" that held by sound and language within the mind. Di Giorgio thus draws attention to physical solitude as well as the solitary processes of thought, or consciousness, as they exist with time, sound, and language vis-à-vis the ordering principals identified throughout the poem.

Many critics have observed that di Giorgio's poetry indeed manifests a solitary mental or "interior" realm associated with what they describe as a lack 
of civility, an absence of moral frameworks, or a disregard for narrative and aesthetic conventions. Ricardo Pallares, for example, associates the subjective forcefulness made possible by the poet's lyricism with the revelations of an unconscious mind. He writes,

There is no narrative element but an intense lyricism since everything is at the service of the expression of the subjectivity of the ' $l$ '. At the same time, poetic recreation elaborates a vision, an interior world that, to add, categories, and conventions are abolished since they give form to confused perturbations of the unconscious mind without an edifying or paradigmatic purpose (44). ${ }^{2}$

Similarly, Herbert Benítez Pezzolano notes that di Giorgio's poems "push from the immediate, evading preambles and tunnels . . . because they lack calming gestures or pacts..." (54). ${ }^{3}$ Luis Bravo extends these ideas regarding the absence of pacts, categories and conventions, to include a lack of morality or ethical grounding. He writes that "[i]n the universe of Los papeles salvajes ...nothing is impossible. There, the movement between the imaginary and the everyday functions in a perverse way, without moral parameters of any kind ..." (259). ${ }^{4}$ Finally, Teresa Porzecanski suggests that the dearth of a commonly experienced order of things in di Giorgio's poetry, including animals, flora and fauna, is indicative of Claude Levi-Strauss' concept of the "savage mind," that is not yet "cultivated," "domesticated," "subject to discipline, [or] a certain order, so as to produce particular results" ("Marosa di Giorgio" 311). However, what if the "results" of di Giorgio's poetic making are found precisely in the tension between an idea of the speaker's solitude and the "moral parameters," "categories and conventions," or "calming gestures or pacts," that are apparently lacking?

The fact that such ordering structures would seem so conspicuously absent or, as in the poem above, present and actively distanced within the poem's structure, suggests that di Giorgio was fully engaging them. In fact, 
she placed these standardizing forces at the center of her oeuvre through spatial, temporal, and linguistic frameworks in order to challenge and readjust the models with which they're engaged. Thus, the deeper question at work here has to do with how poetic form might access and unbind the strains between what di Giorgio understood as the mind's solitude, that is, its individual interpretive processes, and the pulls of communal life, which include the conventions of moral, governmental, juridical, and pedagogical systems as they are negotiated through language. Furthermore, as di Giorgio accesses and unfastens those pulls that hold communal belonging, what forms of belonging, community or affiliation, if any, emerge?

I believe that di Giorgio's poetry emphasizes the relationship between solitude and our modes of communal participation through foregrounding what Cristanne Miller has identified as the "consent of language" in her analysis of Emily Dickinson's poetry ("The Consent" 172). Di Giorgio acknowledged an affinity to Dickinson (1830-1886), a "soul," she explained, "that looks at me and that I look back to" (413)..$^{5}$ However, the Anglo-American poet's incisive, taut, and elliptical verses seem distant from di Giorgio's extravagant poetry paragraphs, an unrestrained movement between the human and animal, intimate sensualities and overt sexual transgression. Nonetheless, di Giorgio coincides with the nineteenth-century poet in her representation of consciousness and language as decidedly solitary entities that, in being so, incite the problem of consent. The "consent of language" is how language gives way to constant modifications, adjustments or changes in meaning, from one person to another, from one moment to the next. Dickinson thought that individuals are not bound to consent to the communal forces that determine the meaning, or life, of words, but rather, that language itself consents to an individual's use of it. The poet's preoccupation with consent reflects her grappling with issues of gender, the primacy of her Calvinist upbringing that emphasized individual exegesis, and her familiarity with John 
Locke's foundational political philosophy regarding language and civil society. Indeed, I place Dickinson and di Giorgio in dialogue with one another, along with Locke, by focusing on what was Dickinson's explicit and di Giorgio's implicit consideration of the "consent of language." Such an analysis helps us understand how di Giorgio's radical approach to language is, ironically, as much bound to her sense of solitude as to her deep concern for what irrevocably binds us, that is, for humanity itself.

\section{Emily Dickinson and the Consent of Language}

Miller suggests that Emily Dickinson connects the "unclear" and elliptical elements throughout her poetry to the physical articulation of meaning and "consent of language." She explains, "The language of Dickinson's poetry is elliptically compressed, disjunctive, at times ungrammatical; its reference is unclear; its metaphors are so densely compacted that literal components of meaning fade. Yet Dickinson believes that a 'syllable' has meaning when it is . . .'made Flesh' in an act of communication” (1). Miller derives this relationship from Dickinson's "A Word made Flesh is seldom."

\footnotetext{
A Word made Flesh is seldom

And tremblingly partook

Nor then perhaps reported

But have I not mistook

Each one of us has tasted

With ecstasies of stealth

The very food debated

To our specific strength-

A Word that breathes distinctly

Has not the power to die

Cohesive as the Spirit
} 
It may expire if $\mathrm{He}-$

"Made Flesh and dwelt among us"

Could condescension be

Like this consent of Language

This loved Philology. (1651)

Miller observes that Dickinson chooses the human word over God's. "[Human language is twice 'loved' (in the adjective and, etymologically, in philo-logos) because it communicates with us; it consents to our manipulation, which in turn replenishes its meaning" (171). God's word, the nature of which is "condescension," on the other hand, does not consent to this continuous, uniquely human, dynamic play of language. A language of "condescension" is a language of terms and meanings that are centrally, univocally determined rather than individually sought and interpreted. Miller continues, "[a]s Dickinson explains in another poem, a word 'just/ Begins to live' when it is spoken" because "in the personae of her poems, Dickinson is a poet of 'consent,' of the shifting transformation rather than the authoritative establishment of meaning" (172). Thus, language consents to what we do to it, consents to its and our own instability, its and our own shifting possibilities. Most important, this consent does not occur between an individual and others who participate in language, but between an individual and language itself.

Dickinson establishes the "consent of language" as the "shifting transformation... of meaning" enabled through a word's material utterance. She thus opens a possibility to how we might think about the relationship between language and consciousness. Consider the dynamic between speech and silence developed in "A word is dead." 


\begin{abstract}
A word is dead
When it is said,

Some say.
\end{abstract}

I say it just

Begins to live

That day. (1212)

The word "Begins to live" when spoken by "I," when the physical gestures of mouth and lungs coordinate to emit that word from the body. In the first stanza, according to "Some," the implied silence, or life of the word, would suggest that the word's ideal place is within the realm of immaterial thoughts as opposed to that of material speech. Thus, Dickinson engages the question of thought as it exists to oneself versus language as it exists among others. Here, when the word is uttered, it gains its individualized vitality. She then sets this question against time. The circumstances of "Begins to live" are determined by the distinctive meaning, or how the speaker uses that word, "that" continuously particular "day." The word's meaning is as much released from any communal approval as it is released from any temporal demands. Individual meaning is not precluded by the past or future, but free from both. Conversely, the word is "dead" when uttered by "Some," when it is collectively determined and held through time from the past and into the future. Dickinson delineates meaning through language as highly individualized, visceral, and unbound from the future and past. She achieves this by focusing on the moment at which a word "just / Begins to live," the moment of consent, or hinge, between consciousness and the communal. 


\section{Consent and Humanity}

"Consent" is the permission for something to happen or agreement to do something. The Latin derivation of "consent," consentire, from con ("with") and sentire ("feeling"), as well as the derivation of "permission," permittere, from per ("through") and mittere, ("send" or "let go"), teaches us more palpably that "consent" means that what is said or done is said or done through or with feeling. Thus, consent is a pathway, the "with" and the "through" between what is "said or done" and an interior experience of "feeling" to which we will add "thinking" or consciousness. By its very definition consent unleashes a fundamental problem of language itself, that is, the problem of how a person's feelings and thoughts - what is "sent" or "let go"- exist with and through language into the future- "something to happen" and "to do something."

The paradigm of consent that is integral to both Anglo and Latin American concepts of natural law and nations, independence, and civil society is largely derived from the philosophical and political theories of John Locke (1632-1704). ${ }^{6}$ Locke's understanding of how consent is bound to things like consciousness, government, progress, time, language and, most important, how we define humanity, helps us address the deep language structures at play in Dickinson's and di Giorgio's poetries. The seventeenth-century founder of British empiricism, like Dickinson, imagines two types of consent-express and tacit - as "Earthly," as natural to "man" and the ways in which he is "naturally free" (Second Treatise 219-220). Express and tacit consent are the explicit and implicit contracts, or contingencies, that fasten individuals to social, political, juridical, and economic systems. While Locke believed that express consent appears to occur clearly, for example, in the signing of a lease, tacit consent is a problem of practice, of everyday activities and everyday language. He 
viewed these forms of consent as highly unstable yet powerful dynamics that fix us interminably within multiple networks outside of and temporally beyond ourselves - "to him and his Heirs forever." Said or done "freely," Locke deemed consent the most binding force of any civil society as it connects us to a compelling web of relationships that "reaches as far as to the very being [and beyond] of any one" (Second Treatise 219-220).

Language, Locke believed, like tacit consent, is the "common conduit" and the "great bond that holds society together." It is the highway through which all of these networks of meaning and power are negotiated. Although Locke had liberated the sign from a necessary relationship to a fixed referent, such as an "original meaning," he links the authoritative meaning of a word through tacit consent to the collective and "familiar use of words" through time (Essay 178; III.ii.1). Therefore, while on the one hand, Locke conceived of language as uniquely human and individualized, on the other hand, it is only so in order for us to progress together from "one generation to another" (Essay 215; III.xi.1). This temporal element results in the idea that a communal valuation of an individual's humanity-her or his actual humanness-lies in that individual's ability to publicly convey the unity of her memories and the activities of her thoughts through time. This means that how we speak and how that language is communally understood or not understood is privileged over how or what we are actually thinking and the ever-changing processes of those thoughts. In this way, a disconcerting turn occurred in Locke's logic when that "mental life" as speech becomes the defining factor of the individual's humanity (Aarsleff 271). ${ }^{8}$ As Charles Taylor has observed, the "primal expressions of human life" are not found in the physical substance of the body, for example, but in the immaterial activities of consciousness as they are spoken and, more important, as they are communally perceived. A person's humanity hinges upon a socially recognizable ability, her ability to think and express, through a consensually 
established language, the supposed unity of her mind..$^{9}$

This is the quandary that both Dickinson and di Giorgio negotiate in their respective poetries. If a word, as Dickinson suggests, "Begins to live" when it is unbound from an original meaning in addition to social recognition, unbound from the past and future, what happens to Locke's idea of humanity? Both poets snip away at the implicit contingencies of his elaborate web. Thus, what both Dickinson and, as I will explain, di Giorgio, put forth is nothing less than a definition of how we evaluate the fundamental, binding language structures of human relationships in as much as these structures define us as human. The moment and processes through which we coordinate sound through breath, lips, jaw, tongue, and larynx, are as important to Dickinson as the word that is actually said, the meaning conveyed, the thoughts thought. Furthermore, whether that physical and temporally specific articulation is socially recognized is secondary to Dickinson, rather than primary. The particularities of individual thought equal the particularities of body and time. A communal language and a collective future are not privileged over the multifarious possibilities of a present meaning. In fact, to be public in language is to deform thought, meaning, sound and an individual's identity itself, as in the poem "I'm Nobody! Who are you?":

I'm Nobody! Who are you?

Are you-Nobody-too?

Then there's a pair of us!

Don't tell! they'd advertise-you know!

How dreary-to be-Somebody!

How public-like a Frog-

To tell your name-the livelong June-

To an admiring Bog! (288) 
What Miller identifies as the unclear and elliptical elements of Dickinson's poetry are here again linked directly to the issue of public utterance. Terms are not clarified, delineated, or established as they are placed in contrast, but unbound, even made immense, terrifying and vast, in their indefiniteness. We are led more toward what words do not mean than to what they do mean. "Nobody" risks being made more public ("they'd advertise") if discovered, while "Somebody's" mouth is disfigured by the very sound he utters, which is his own name. He is metamorphosed in his condemnation to repeat a meaningless, formless grunt "like a Frog" the "livelong June." The "Bog" is the distorted, gazing mouth, sound and ears of communal recognition. To speak publicly, to heed to a "Bog's" confirmation, is for a person to deform the name by which he is called forever. Thus, to be human, for Dickinson, is to speak as "Nobody," regardless of others and regardless of the future.

\section{Marosa di Giorgio, Sound and Solitude}

Marosa di Giorgio would also focus on individualized meaning as contingent upon solitude, the physical articulation of words, and a release from the future. Like Dickinson, this would be her model for the "consent of language," which is, again, the shifting transformation, as opposed to the authoritative or communal, establishment of meaning. Indeed, the relationship between the mind's individual work in language and the forces that strive to systematize such work through explicit and implicit forms of consent constitutes one of the foundational energies of di Giorgio's oeuvre, particularly during Uruguay's military dictatorship from 1973 to 1985. Di Giorgio, who lived from 1932 to 2004, published a significant portion of her oeuvre during this period: La guerra de los huertos (1971), Está en llamas el jardín natal (1971), Clavel y tenebrario (1979) and La liebre de marzo (1981). In this essay I consider the second and third books of this group published in di Giorgio's collected works, Los papeles salvajes (The Savage Papers) in 2000. 
Throughout the 1970s and '80s, Uruguay, like much of Latin America, lived under a climate of terror and institutionalized violence enforced through imprisonment, torture and persecution while thousands were disappeared..$^{10}$ The government embarked upon a multi-front effort to circumscribe and regulate every mode of communal participation and effort at meaning within the highly restricted military state. Those involved or associated with militant as well as non-militant left-wing organizations, in addition to many who worked in cultural fields, such as journalism, theatre, education and psychology, were particularly targeted." Individuals who were not imprisoned or disappeared suffered under the pressures of censorship, constant surveillance and the junta's methodical privation of freedom of conscience, speech, assembly, liberties, and civil rights. However, Mauricio Rosencof (1933-), a political activist, poet, and playwright explains that as early as 1966 there were "political prisoners, and 'extraofficially,' the governments headed by Pacheco and his successor, Juan María Bordaberry, were dictatorial in nature. Pacheco governed by decree, established a 'death squad,' closed newspapers, censored songs, and killed students. By 1972 Uruguayan prisons and barracks were filled to capacity. Torture, rape and death were the order of the day even before the coup of February 9 (1973). This remained the state of affairs until March 1984" (120122). Thus, during the years leading up to and throughout the dictatorship, intellectuals were interpreting what Teresa Porzecanski has called "a reality under siege" ("Fiction and Friction" 216). Writers were forced to contend with the regime's official discourse that "emblematically eluded any semblance of truth" and imposed a "world . . . described consensually" ("Fiction and Friction” 216). Works such as Idea Vilariño’s (1920-2009) Pobre mundo (1966), Cristina Perri Rossi's (1941-) Evohé (1971) and Amanda Berenguer's (1921-2010) Materia Prima (1966), question what types of language might undermine such an imposed consensus at the same time that they maintain a certain political efficacy. Consider, for example, Berenguer's "Comunicado": 
Malas palabras obscenas locas

lunfardas bárbaras otras

que puedan con esto:

descuartizada la forma

valgan las tripas

a cambio de la apariencia.

Lo que se quiere decir

no se dice, se hace. (33)

[Bad words obscene insane

lunfardic barbaric others

that can handle this:

form dismembered

let the entrails count

for what is seen.

What you want to say

you don't say, you do.]

Words, like bodies, that have been dismembered or quartered through torture, speak for themselves. For Berenguer it seems that only peripheral, broken, exposed and even gutted forms might be politically viable. Mario Benedetti (1920-2009) and Hugo Achugar (1944-) identify a crisis in the ability to produce meaning due to the suppression or destruction of sound itself. Benedetti's "De lo prohibido" ("On the Prohibited") from Cotidianas: 1978-1979, lists a range of forbidden cultural markers, types of people, groups, emotions, and language as well as any oral or corporeal utterance.

Prohibidos los silencios y los gritos unánimes

las minifaldas y los sindicatos

artigas y gardel

la oreja en radio habana

el pelo largo la condena corta 
josé pedro varela y la vía lactea

la corrupción venial el pantalón vaquero

los perros vagos y los vagabundos

también los abogados defensores

que sobrevivan a sus defendidos

y los pocos fiscales con principio de angustia

prohibida sin perdón la ineficacia

todo ha de ser eficaz como un cepo

prohibida la lealtad y sobre todo la tristeza

esa que va de sol a sol

y claro la inquietante primavera

prohibidas las reuniones

de más de una persona

excepto las del lecho conyugal

siempre y cuando hayan sido

previa y debidamente autorizadas

prohibidos el murmullo de las tripas

el padrenuestro y la internacional

el bajo costo de la vida y la muerte

las palabritas y las palabrotas

los estruendos molestos el jilguero los zurdos

los anticonceptivos pero quién va a nacer. (111-112)

[Prohibited: unanimous silences and screams

miniskirts and unions

artigas and gardel

an ear to radio havana

long hair condemned short

josé pedro varela and the milky way

venial corruption and jeans

lazy dogs and vagabonds

also defense attorneys

that outlive the people they defend 
and the handful of prosecutors with the onset of anguish

prohibited without pardon: inefficiency

everything must be efficient like the stocks

prohibited: loyalty and above all sadness

the kind that goes from sun to sun

and of course the disconcerting spring

prohibited: meetings

of more than one person

except in the conjugal bed

when and only when it has been

previously and duly authorized

prohibited: intestinal murmurs

the our father and internationals

the low cost of living and death

good words and bad words

bothersome racket the goldfinch lefties

contraceptives but how could anyone be born.]

And here is Achugar's poem from Textos para decir María (1976):

Lento Uruguay rico en praderas

con cenizo fonema

calzo mi lengua y te nombro:

tu carne no se levanta. (22)

[Slow Uruguay rich in prairies

with ashen phonemes

I shoe my tongue and name you:

but your flesh is not roused.]

For Achugar, the naming of Uruguay through prosopopoeia and "ashen phonemes" reveals ineffectual poetic techniques and, indeed, a dead language. 
This state of language and poetic form in turn reflects Uruguay itself, a country whose "flesh is not roused," that is, a dead country. Benedetti and Achugar establish the materiality of language, which includes the tongue as well as phonemes, screams as well as a hungry, murmuring stomach, as the ground zero of meaning. Indeed, for these poets, the condition of such a language that speaks directly to a communal reality constitutes nothing less than the condition of possibility for human life. "[B]ut how," writes Benedetti above, "could anyone be born."

Di Giorgio, on the other hand, never questions the efficacy of language or its political viability, because she deems language an experience of solitude and, in being so, is first one's own. Consider, for example, poem "21" from Clavel y tenebrario:

Existe un hermosísimo idioma, cuyas palabras parecen casitas hechas con hongos. A su lado, palidecen las más bellas letras rúnicas.

Lo descubrí una tarde, y, no, lejos: aquí, nomás, mientras avanzaba entre las boticas de los eucaliptos, a la hora en que las paredes se colman de estrellas, y desde los árboles y el cielo, caen pastillas y perlas, vi el idioma, y lo entendí, enseguida, como si siempre, hubiera sido el mío. (Clavel 189)

[An exquisite language exists, and its words look like small houses made with mushrooms. Beside them, the most beautiful runic letters pale.

I discovered it one afternoon, and, not, far: right here, as I walked among the eucalyptus pharmacies, when walls are filled with stars, and pellets and pearls fall from the trees and sky, I saw the language, and understood it, right away, as if it had always, been my language.]

The "exquisite language," like the "nest of tulle" in poem "104," contrasts the cultivated domain of runic letters, like "notebooks" and "pencils." The speaker has discovered a language that is already understood and proper to her- "it had always, been my language." That is, language consents to the individual's use 
of it. However, between the identification of its existence and the expression of the speaker's ownership, the poetic voice delights in the process of what would seem an unintended and unexpected discovering. Even though we're presented with a brief list of natural elements, the effect is slightly dizzying as we're drawn by a certain familiarity of the image and then unsettled by it. Mushrooms, eucalyptus trees, stars and sky are all common things among nature. However, a language of runic letters, pellets, pharmacies, and pearls here are not common natural elements. The list, more than describe the details of a particular landscape, takes pleasure in it and, more important, the "exquisite language" is contingent upon this pleasure.

Roland Barthes would call di Giorgio's poem a "text of bliss." Barthes suggests that such a text "imposes a state of loss" as it "discomforts (perhaps to the point of a certain boredom), unsettles the reader's historical, cultural, psychological assumptions, the consistency of his tastes, values, memories, brings to a crisis his relation with language" (14). In the poem above, even though the "exquisite language exists" in the present, it had not been accessible or commonly known. The poetic voice then retrieves that language as it, nonetheless, remained in its original, not commonly known state. Thus, the pleasure of the recuperation of this language inevitably involves loss. We're led from the present tense to a nostalgic imperfect tense (in Spanish), to the past perfect subjunctive, "had always, been." While the shift in tenses might suggest an ahistorical experience, what the preterit, "discovered," and "right here" trigger is an unsettling relationship between the poem's pleasure and an historical indexing. Through the folding back and over of these tenses, as in Dickinson's "A word is dead," di Giorgio unbinds that "exquisite language" from any future contingencies. The delicate bliss of her texts signals a language of one's own that, in this case, as Barthes suggests, unexpectedly "brings to a crisis" the reader's relation with the implicit contracts of Locke's temporal tethers (14). Here there is certainly no "progress together." Dickinson's texts 
also manifest this "bliss" in their focus on the present, their attention to the minute details of nature, their irregular punctuation and apparently simple rhymes that, simultaneously, reveal sharp social critique or extraordinary philosophical and theological insight. While di Giorgio seems dislodged from any social or political denunciation, she is in fact renegotiating a sense of individual ownership and vitality regarding the conditions of language within a society in which those conditions have been besieged.

Similarly, in poem "19," di Giorgio intersects the senses of pleasure and loss with the spontaneous recitation of memorized "lines" among "cedar and carob trees." However, the speaker emphasizes that these recitations do not require the public's recognition or participation:

Hacíamos representaciones en los jardines, a la caída de la tarde, junto a los cedros y las algarrobas; la obra era improvisada, ahí mismo, y yo, siempre, tenía miedo de perder la letra, aunque, nunca, ocurrió tal cosa. íbamos, de aquí para allá, entre los cedros y los naranjos, y acudían a espiarnos, a escucharnos, los habitantes de todas las casonas vecinas.

También, teníamos algunos animales en el elenco; habían aprendido a moverse en un escenario, a vestirse, a calzarse, y hasta decían algunas palabras.

Desde los doce a los veinte años, representé en todos los jardines.

Pero, después, todo se deshizo.

$\mathrm{Y}$ los animales volvieron al bosque a continuar su vida silenciosa. (Clavel 188-189)

[We recited in the gardens, at sunset, near the cedar and carob trees; the show was improvised, right there, and I, always, feared forgetting my lines, even though, never, such a thing occurred. We would move, from here to there, between the cedars and orange trees, and they would come to spy on us, to listen to us, the inhabitants of all the neighboring country houses.

We would include some animals in the cast as well; they had learned to move upon a stage, to dress up, wear shoes, and even said a few words.

From twelve until twenty, I performed in every garden. 
But, then, it was all undone.

And the animals returned to the woods to continue their silent life.]

Although it would appear that the "inhabitants of nearby houses" assume the role of addressees, of "listen[ers]," their presence, like Dickinson's admiring "Bog," is unnecessary for the representation to occur; the neighbors "spied." Furthermore, the poem points to rudimentary or initial representational processes. The "show was improvised, right there," the animals only "learned to ... . [say] a few words," and upon the speaker's transition to adulthood, "it was all undone." In addition to being independent of communal reciprocity, here representation is not an accomplished or finite act, but a developmental process.

In di Giorgio's poetry, this blissful encounter with nature, and any type of partial or full metamorphoses, is tied to the equally pleasurable acquisition of language. In poem "21" from the 1971 book, Está en Ilamas el jardín natal [The Garden of My Birth Is on Fire], the complete metamorphosis of the speaker involves the "birth" of lilies and the incomplete transition from babble to speech.

De pronto, nacieron las azucenas:

en el aire oscuro de la noche, del atardecer, abrieron sus caras blancas, sus fosas blancas, ¿qué iba a hacer yo, con esa gente blanquísima?

Me ocurrían cosas extrañas, silabeaba, deletreaba como si sólo tu-viera dos o tres años, me parecía que veía, a lo lejos, flotar en el aire, a papá y a mamá, o que escuchaba conversaciones anticísimas [sic] en un idioma que sólo se conocía en la casa. Tal vez, me iba a morir. Me arrodillé, el cabello me cubrió el rostro; quise rezar y llorar. Pero, sólo me erguí, y con un paso de bailarín, de sonámbula, Ilegué hasta la casa; mamá proseguía su eterna labor, pasé al través de las habitaciones, volando, logré izarme sobre las arboledas; me había vuelto un ser extraño, un monstruo, con muchas alas, volaba, planeaba, mirando siempre hacia allá, hacia el lugar donde habían nacido las azucenas. (173) 
[Suddenly, the lilies were born:

in the dark night air, at sunset, they opened their white faces, their white hollows. What would I do, with such white people?

Strange things occurred to me, I syllabicated, spelled out as if I were only two or three years old, and it seemed that I could see, far away, floating in the air, mama and papa, or that I could hear antient conversations in a language that was only known at my house. Maybe, I was going to die. I kneeled down, hair covered my face; I wanted to pray and cry. But, I just stood up straight, and with a dancer's or a sleepwalker's step, I arrived to the house; mama went about her never-ending work, I passed through the rooms, flying, I managed to hoist myself up on the groves; I had become a strange being, a monster, with many wings, flying, gliding, always watching over there, over in the place where the lilies had been born.]

The lilies' "white faces" incite the speaker to lose her human form as well as her voice, or the capacity to speak a fully developed language. Susan Stewart has considered the loss of voice as it relates to individuation in Ovid's Metamorphoses. She suggests that "[f]or these characters, losing a capacity for speech is yoked not just to the loss of their human form but also to the loss of the form of their persons or proper names-that name by which they are called or summoned into the reciprocity of living human speech" (61). Thus to be human, for Ovid, is to possess the human form but, more important, to be distinguishable from others through the proper name as we are "summoned into the reciprocity" of spoken language. However, for di Giorgio, to be human is to recall the sound processes that come before we are "summoned into the reciprocity" that is the decipherability of our proper names.

The learning and loss of language here involves the memory of language itself through sounds that tie us as much to the animal and natural world as to our own physical stages of development. Daniel Heller-Roazen has explored the memory of linguistic sounds lost upon a child's acquisition of language. Roman 
Jakobson, he explains, learned that the repetitive vocalizations of infants, called echolalia, contained all possible human sounds. Heller-Roazen thus asks: "Do the languages of the adult retain anything of the infinitely varied babble from which they emerged? If they did, then it would be only an echo, since where there are languages, the infant's prattle has long ago vanished, at least in the form it once had in the mouth of the child who could not yet speak. It would be only an echo, of another speech and of something other than speech: an echolalia, which guarded the memory of the indistinct and immemorial babble that, in being lost, allowed all languages to be" ("The Apex" 11-12). When an infant enters into the formality of a common language, the majority of those echolalic sounds are lost except, Heller-Roazen later suggests, within poetic form as, for example, echoes of syllabic count ("Persian" 195-202). Di Giorgio's poetry, always nostalgic, attempts to recuperate the idea of those possibilities at the moments before they're dissolved in the centripetal pull of that communal language. In this sense, words, for di Giorgio, are embedded with the loss of what allowed them to be. But this loss, as both di Giorgio and Heller-Roazen suggest, might be recuperated-or at least remembered as a future possibility - through sounds as they are accessed in poetic form.

What could be more pleasurable than the echolalia of a child? But who is more in need of the communal than that child as she is completely dependent on her family or other adults who surround her? Although di Giorgio interrupts the call for reciprocity within a common language, in poem "21" ("Suddenly, the lilies"), to syllabicate or spell out like an infant learning to speak involves the memory of a language that is proper to the speaker's family. It is as if those particular sounds recall what is genetically embedded, or known differently, among familial relations. But the poem identifies syllabication as well as the "conversaciones anticísimas" or "antient conversations," like a familial idiolect. "[A]nticísimas," an incorrect spelling of "antiquísimas," refers to the word's dual meaning through an etymological reference: "antiguo" comes from 
the Latin "anticus," temporally "before" or "former." The word also refers to "ante," as in physically "before" or "in front of." "[A]nticísimos" speaks to the familial relations of words, to language here among us like family members whose genetically present ancestors are nonetheless inaccessible to us. Again, this is Barthes' sense of loss within the text of bliss that, for di Giorgio, is the condition of language. But what the connection between an echolalic state and familial relations stresses is an absolute dependency - that of the childas the foundation of our humanity. Solitude is the memory of this relationship within language. Furthermore, for di Giorgio, the poetic voice that loses the capacity for speech and metamorphoses into a flying "monster," is actually becoming more human.

Thus, the poet's interruption of communal consent unsettles Locke's sense of contingent and reciprocal communal bonds to replace them with a notion of the familial community. What makes di Giorgio's community familial, that is genetically or etymologically connected, however, is how that family is retrieved through sounds and common longing. Here is poem "23" of Está en llamas el jardin natal:

Oh, volver a la propiedad familiar, a la tarde cruzar el campo donde la hortensia levanta su cara de humo, de pluma, su cabeza murmurante, su sombrero de vidrio, de turquesas, donde nace la honga feroz, la seta de venenosa espuma, cruzar los campos durmiendo, con los ojos bien abiertos, bien cerrados, sin equivocarse nunca, sin caer sobre las zarzas, las fogatas, los otros seres que van por el campo soñando, hasta aquella ciudadela siempre visible y perdida, entrar en ella, cenar, pecar furiosamente.

Años sin fecha, cerrados como pastos, la neblina. (174)

[Oh, to return to the familial property, in the afternoon cross the field where the hydrangea lifts her smoky face, of plume, her murmuring head, her hat made of glass, of turquoises, where the ferocious fungus, the venomous froth mushroom, traverse the countryside asleep, with eyes wide open, sealed shut, 
without ever making a mistake, without stumbling on the briars, the bonfires, or other beings that wander through the countryside dreaming, to that always visible and lost citadel, go in there, dine, and sin furiously.

Years without date, closed like pastures, the fog.]

The speaker, again, longs to go back to what is always present, like the discovery of a language that is already known or the "antient conversations." This going back is accessed through the unconscious dreaming mind whose eyes are "wide open" yet "sealed shut." But once the focus of the poem, the "always visible and lost citadel," like the already known language, is reached, the poem is overcome by a sense of loss. Furthermore, the presence of "other beings," also dreaming and wandering, emphasizes a common search for what is ultimately also "familiar," that is, intimately and singularly known, yet "lost" to all. While other poems establish the speaker's relationship to the "consent of language," which involves a necessary distance from governmental, juridical, or pedagogically ordering principles, here is the idea of a governing community. Di Giorgio's “citadel," like echolalia, is one of sounds that allowed all languages to be. We access this "citadel" through the bliss of poetry, the genre that remembers the learning of language, the moment at which all languages and meanings were possible. And to return to such a place would be to "sin furiously" against a "world...described consensually." It would be to achieve a crisis in one's relationship to language and reject the most basic structures through which communal consent is imposed. But what is most radical about di Giorgio's "citadel" is that it is a place in which individuals, like small children, are completely reliant upon those around them. This reliance is expressed through sound and, in this poem, the senses.

Dickinson's and di Giorgio's ideas of solitude are definitions of what it means to be human among others. However, while for Dickinson, solitude is a state that does not involve nostalgia for the past or longing to congeal 
with others into the future, for di Giorgio, it is language's painful ever-present memory of togetherness. Such togetherness, ironically, is the moment we are fully vulnerable upon others as in a childlike state, which demands even more interconnectedness than Locke's sense of the communal in that the latter would imply consent, something a child cannot achieve. Sounds signify our dependency upon others before the terms of that dependency are circumscribed by our actual ability to speak it. Solitude is what di Giorgio believes to be our embedded memory of the "citadel," of that intimate and precarious interconnectedness before our coming into languages which sets more rigid (although, perhaps equally precarious) terms of participation in motion. And if there is a place to relieve this solitude, or at least, to acknowledge it, it is in the lost citadel of poetic form.

\section{Notes}

This article first appeared in Spanish as "Soledad y el consentir del lenguaje: Marosa di Giorgio y Emily Dickinson" Revista de la Biblioteca Nacional de Uruguay, vol. 13, 2017, pp. 125-45. The author and editors wish to thank the original publishers for the permission to publish this translated version.

1 This and all translations of poetry and secondary sources are my own.

2 "No hay narratividad sino un intenso lirismo ya que todo está al servicio de la expression de la subjetividad del yo. Al mismo tiempo, la recreación poética elabora una visión, un mundo interior en el que, por añadidura, quedan abolidas todas las categorías y convenciones desde que da forma a confuses perturbaciones del inconsciente sin propósito edificante ni paradigmático." (Pallares 44).

3 "Los poemas y relatos de Marosa di Giorgio empujan de inmediato, evadiendo preámbulos y túneles-a lo Lewis Carroll en el descenso de Alicia-, ya que carecen de gestos o pactos tranquilizantes con los lectores, tales como los de espacio mitico, o alegoría, o categorías de lo fantástico." (Pezzolano 54).

4 "En el universo de Los Papeles Salvajes... nada es imposible. Allí, el trasiego entre lo imaginario y lo cotidiano se comporta de manera aviesa, sin parámetros morales de ningún tipo..." (Bravo 259).

5 Di Giorgio wrote a short essay on Emily Brontë and Emily Dickinson called "Emily y Emily" that was published in the December 1995 issue of Posdata. She describes 
Dickinson as follows: “En su adolescencia acaso brilló fugazmente en las reuniones sociales del pueblo. Luego, se volcó de modo definitivo, sobre sí misma, y al interior de su caserón." (159) ("During her adolescence perhaps she shined briefly in the towns' social gatherings. Then, she turned definitively, upon herself, to the interior spaces of her family home.")

6 For a comparative study of the extent to which Locke's theories informed political philosophy in the US and Latin America, see Chiaramonte.

7 At the same time Locke cannot ignore the fact that to unleash meaning to consensual collective usage is to open a Pandora's box of what he feared would be incorrect usage. Throughout Book III of An Essay Concerning Human Understanding (1689) is a desire to fix language, moderate and establish the bounds of meaning, make words count mathematically in such a way that they, as precisely as possible, match particular yet commonly recognized and understood ideas. In the Book's first chapter that addresses the "abuse of words," such "abuses" include "words without any, or without clear ideas," "inconsistency," "obscurity," "empty speculations," "taking a word for the thing," and even "figurative speech." Again, because speech, Locke concludes, is "the great bond that holds society together, and the common conduit, whereby the improvement of knowledge are conveyed from one man, and one generation to another" we must "consider what remedies are to be found for these inconveniences above-mentioned." (III, x-xi: 208-215).

8 As Hans Aarsleff has pointed out, "[i]nstead of securing that language kept its place as the docile servant of thought, [Locke]... gave so much power to words that they were poised to become the very agency of mental life... It became the central doctrine of this new conception that language (as speech) has a human origin and that both its creation and its continued use are primal expressions of our humanity." See "Locke's Influence," 271. Aarsleff here refers to Book IV, Chapter vi, $\S 1$ of the Essay.

9 For a consideration of Locke's influence on modern concepts of "identity" and time, see Taylor.

10 During the first four years of the dictatorship, Uruguay had the highest per capita of political detainees in the world. Overall, more than 60,000 people were imprisoned in this country. See Lessa and Druliolle; Pearce; Sondrol 196; Weinstein.

11 For a consideration of the dictatorship's impact on cultural fields in Uruguay see Sosnowski and Popkin; Rey Tristán; Moraña. 


\section{Works Cited}

Aarsleff, Hans. "Locke's Influence." The Cambridge Companion to Locke. Ed. Vere Chappell. Cambridge UP, 1999, pp. 252-89.

-, “¿Kitsch, vanguardia o estética camp? Apuntes fragmentarios sobre Marosa di Giorgio: acerca de la imposibilidad de atrapar a Marosa," Hispamérica, vol. 34, no. 101, Aug. 2005, pp. 105-110.

Achugar, Hugo. Textos para decir María. Caracas: Monte Avila Editores, 1976.

Barthes, Roland. The Pleasure of the Text. Translation by Richard Miller. Hill and Wang, 1975.

Benedetti, Mario. Inventario uno: poesía completa 1950-1985. Buenos Aires: Editorial Sudamérica, 2001.

Benítez Pezzolano, Herbert. "Marosa Di Giorgio en lasbocas de la luz." Interpretación y eclipse: Ensayos sobre literature uruguaya. Montevideo: Librería Linardi y Risso, 2000, pp. 51-61.

Berenguer, Amanda. "Comunicado," Poesía rebelde uruguaya: 1967-1971. Ed. Hugo Achugar. Montevideo: Biblioteca de marcha, 1971.

Brantley, Richard E., “Emily Dickinson's Empirical Voice," Symbiosis: A Journal of AngloAmerican Literary Relations, vol. 15, no. 1, April 2011, pp. 205-31.

Bravo, Luis. "Marosa di Giorgio: lecturas herme(neú)ticas de c.dice Los papeles salvajes," Voz y palabra: historia transversal de la poesía uruguaya 1950-1973. Montevideo: Estuario Editora, 2012, pp. 353-75.

Chiaramonte, José Carlos. "The Principle of Consent in Latin and Anglo-American Independence." Journal of Latin American Studies, vol. 36, no. 3, Aug. 2004, pp. 563-86.

Dickinson, Emily. The Complete Poems of Emily Dickinson. Ed. Thomas. H. Johnson. Little Brown and Company, 1961.

Di Giorgio, Marosa. Los papeles salvajes: Edición definitiva de la obra poética reunida. Ed. Daniel García Helder. Buenos Aires: Adriana Hidalgo, 2008.

—, "Emily y Emily." Pasajes de un memorial: Al abuelo toscano Eugenio Médici. Ed. Leonardo Garet. Salto: Centro Comercial e Industrial de Salto, 2006. 158-9. First published in Posdata, December, 1995.

Echavarren, Roberto. "Marosa Di Giorgio, Última poeta del Uruguay." Revista Iberoamericana, vol. 58, no. 160-1, July-Dec 1992, pp. 1103-15. 
Heller-Roazen, Daniel. Echolalias: On the Forgetting of Language. Zone Books, 2005.

Lessa, Francesa and Vincent Druliolle, eds. The Memory of State Terrorism in the Southern Cone: Chile, Argentina, and Uruguay, Palgrave Macmillan, 2011.

Locke, John. Second Treatise of Government. Hacket, 1980.

-, An Essay Concerning Human Understanding. Ed., Intro., and Notes by Kenneth P. Winkler. Indianapolis: Hackett Publishing Company, Inc., 1996.

Miller, Cristanne. Emily Dickinson: A Poet's Grammar. Harvard UP, 1995.

Moraña, Mabel. "Ideología y autocensura en la producción literaria: El caso de la lírica uruguaya, cinco años de dictadura (1973-1978)," Revista de crítica literaria latinoamericana, vol. 6, no. 11, 1980, pp. 65-84.

Olivera-Williams, María Rosa.“La imaginación salvaje: Marosa di Giorgio.” Revista Iberoamericana, vol. 71, no. 211, April-June, 2005, pp. 403-16.

Pallares, Ricardo. "Marosa Di Giorgio.” Tres mundos en la lírica uruguaya actual: W. Benavides, J. Arbeleche, M. Di Giorgio. Montevideo: Ediciones de la Banda Oriental, 1992, pp. 43-58.

Pearce, Jenny. Uruguay: Generals Rule, Latin America Bureau, 1980.

Porzecanski, Teresa. "Fiction and Friction in the Imaginative Narrative Written inside Uruguay.” Repression, Exile, and Democracy: Uruguayan Culture. Ed. Saúl Sosnowsky and Louise B. Popkin. Trans. Louise B. Popkin. Duke University Press, 1993, pp. 21323.

—,"Marosa Di Giorgio: Uruguay's Sacred Poet of the Garden." A Dream of Light and Shadow: Portraits of Latin American Women Writers. Ed. and Intro. Marjorie Agosín. University of New Mexico Press, 1995, pp. 303-14.

Rey Tristán, Eduardo, ed. Memorias de la violencia en Uruguay y Argentina: golpes, dictaduras, exilios, 1973-2006. Santiago de Compostela, Spain: Centro Interdisciplinario de Estudios Americanistas “Gumersindo Busto,” 2007.

Sondrol, Paul C. "1984 Revisited? A Re-Examination of Uruguay's Military Dictatorship" Bulletin of Latin America Research, vol. 11, no. 2, 1992, pp. 187-203

Sosnowski, Saúl and Louise B. Popkin, eds. Repression, Exile, and Democracy, Duke University Press, 1993.

Taylor, Charles. "Locke's Punctual Self," The Sources of the Self: The Making of the Modern Identity, Harvard University Press, 1989, pp. 150-76.

Weinstein, Martin. Uruguay: Democracy at the Crossroads, Westview, 1988. 